\title{
WELDABILITY OF MICRO-ALLOYED HIGH-STRENGTH PIPELINE STEELS USING A NEW FRICTION WELDING VARIANT
}

\author{
K. Faes ${ }^{1}$, P. De Baets ${ }^{2}$, A. Dhooge ${ }^{1,2}$, W. De Waele ${ }^{2}$, R. Denys ${ }^{2}$, \\ E. Van Der Donckt ${ }^{3}$ and D. Delbaere ${ }^{3}$ \\ ${ }^{1}$ Belgian Welding Institute, Belgium \\ ${ }^{2}$ Ghent University, Laboratory Soete, Belgium \\ ${ }^{3}$ DENYS NV, Belgium
}

\begin{abstract}
An innovative welding method for fully automatic joining of pipelines has been developed. The proposed welding procedure is a variant of the conventional friction welding process. A rotating intermediate ring is used to generate heat necessary to realise the weld. The working principles of the welding process are described. The weldability of the micro-alloyed high-strength pipeline steel API-5L X65 is experimentally investigated. It was found that the new welding process is suitable for joining this material. When welding with a sufficiently low heat input, a high weld quality is obtained. Under these circumstances the weld strength, ductility and impact toughness are high and fulfil the requirements of the commonly used standard EN 12732 for joining pipes.
\end{abstract}

Keywords : friction welding, pipelines, micro-alloyed high-strength pipeline steels

\section{INTRODUCTION}

Unprecedented demand growth for natural gas and petroleum is fuelling an enormous global need for pipeline construction in the coming years. According to pipeline industry analysts [1], up to $237.000 \mathrm{~km}$ of new pipeline construction is announced worldwide. Based on reasonable assumptions, this figure implies not less than 15 to 20 million welds to be made. Obviously this prospect is representing a robust growthopportunity for companies involved in pipeline construction (construction contractors, welding subcontractors, engineering offices, welding equipment manufacturers, etc.). But at the same time it is putting an unseen challenge in terms of productivity, quality assurance, employee safety and environmental impact for welding operations.

Traditional manual welding techniques have several limitations in relation to the above mentioned challenges. An increasing end-user driven demand for high-strength steels for pipeline applications is observed. These steel grades typically are more difficult to weld with the conventional technology. The quality requirements are increasingly stringent and there is a need to guarantee a constant, reproducible quality. Moreover, it is difficult to find skilled welders and it is foreseen that the shortage will increase in the coming years.

\section{PRINCIPLE OF THE NEW VARIANT OF THE FRICTION WELDING PROCESS}

In order to cope with the challenges, several automatic welding processes have been developed [2-7]. Friction welding [8] is one of the processes which has been investigated for pipeline girth welding. Friction welding is a forge welding process in which the heat is generated as a result of the friction between two surfaces rubbing against each other under controlled axial pressure. Conventional friction welding is however not suitable for joining long components, such as pipelines, since these parts cannot be rotated for practical reasons.

To enable pipelines to be welded using friction welding, a new variant of the conventional process has been developed, which is called "FRIEX". The major difference of the new variant with conventional friction welding is that a "filler material" in the form of a solid ring is used. The welding ring is placed in between the pipes, and rotating the ring under an axial pressure generates the required friction and associated heat [913].

After the pipes are brought into contact with the welding ring, the friction between the rotating ring and the pipes increases the temperature in the contact area, until the forge temperature is reached. At that moment, the rotation of the ring is rapidly stopped, and the axial force is increased to the final forge force. After welding, the remaining welding ring material and welding flashes are removed using automated turning and milling mechanisms. 


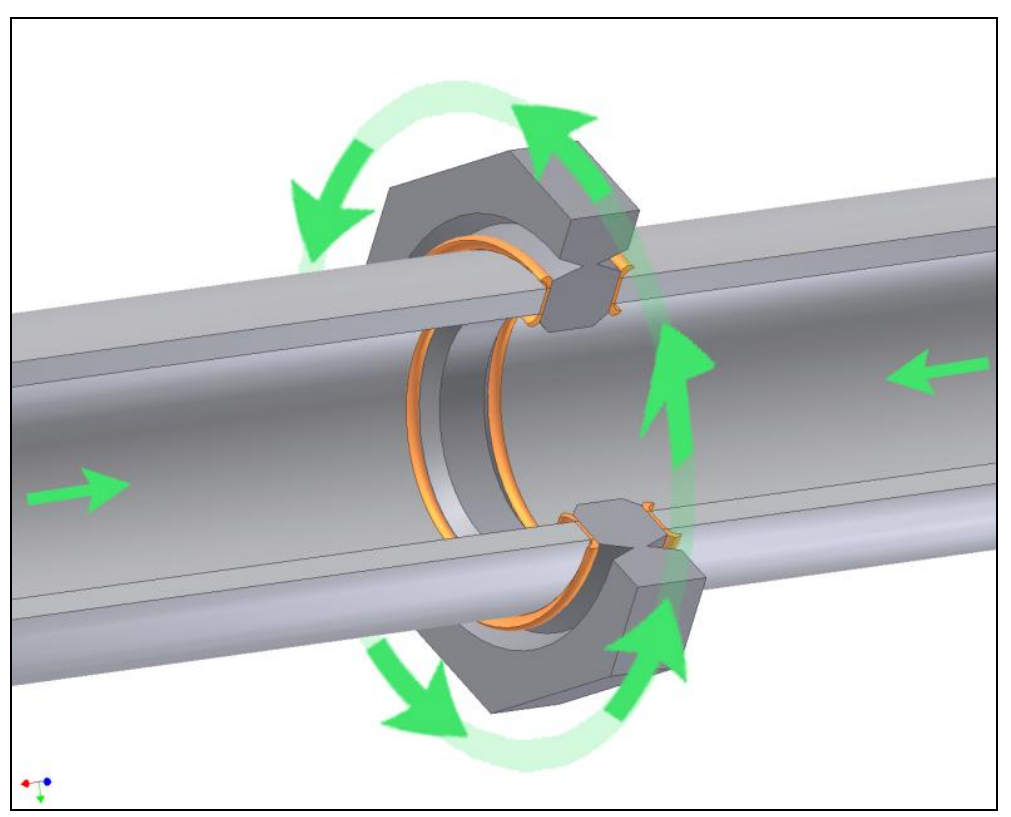

Figure 1. Principe of the welding process

\section{EXPERIMENTAL RESEARCH}

The feasibility of the new variant of the friction welding process for joining pipes has been successfully proven for welding pipes in conventional rolled pipeline steels API-5L X42 and X52, with a ferritic-pearlitic microstructure. The welding trials have been performed with pipes with an outer diameter of resp. 88,9 and $114,3 \mathrm{~mm}$, using a small-scale test set-up [9-13].

For these pipeline steels the influence of the welding parameters on the weld properties was investigated. A work program was established to examine experimentally the factors affecting the toughness properties of welded pipes. The general aim was to study the influence of the process parameters in order to be able to select the appropriate process parameters for ensuring high-quality welds.

After parameter optimisation high-quality welds could be realised, which fulfilled the requirements of the often used standard EN 12732; "Gas supply systems - Welding steel pipework - Functional requirements". This frequently used standard contains the production and testing requirements of weld joints for installation of onshore steel pipelines and pipework used in gas supply systems. Also the welding ring material, shape and dimensions were optimised. Welding rings with a compatible microstructure, strength and toughness were used.

The ever increasing demand for energy world wide requires the construction of high pressure gas transmission lines with the greatest possible transport efficiency, in order to minimise the cost of pipeline construction and gas transportation. This is particularly the case when large distances have to be covered. Nowadays the trend is therefore using pipelines of larger diameter and/or increasing the operation pressure of the pipeline. This necessitates the use of higher-strength steel grades to avoid a large pipe wall thickness. In consideration of the future acceptance, the welding process was validated for joining highstrength micro-alloyed pipeline steels, such as API-5L X65, X70 and X80.

\section{LARGE SCALE EXPERIMENTAL TEST SET-UP}

A large full-scale test set-up was designed and built for welding pipes up to a diameter of $504 \mathrm{~mm}$ (see Figure 2). The axial friction and forge force is exercised by two large hydraulic cylinders. The maximum available force equals $3000 \mathrm{kN}$.

The rotation of the welding ring is realised by using 6 hydraulic motors, each connected to a planetary gear system (gear ratio 1:3,25), which are in their turn mounted on a central placed large gear transmission with a gear ratio of $1: 4$. The total gear ratio thus equals $1: 13$. The welding ring is mounted in the large hollow gear wheel of the gear system, in a rigid clamping device able to transmit the drive power and torque. The 
maximum rotation speed of the welding ring is $250 \mathrm{rpm}$. The available effective drive power and torque equals $600 \mathrm{~kW}$ and $100.000 \mathrm{Nm}$ respectively.

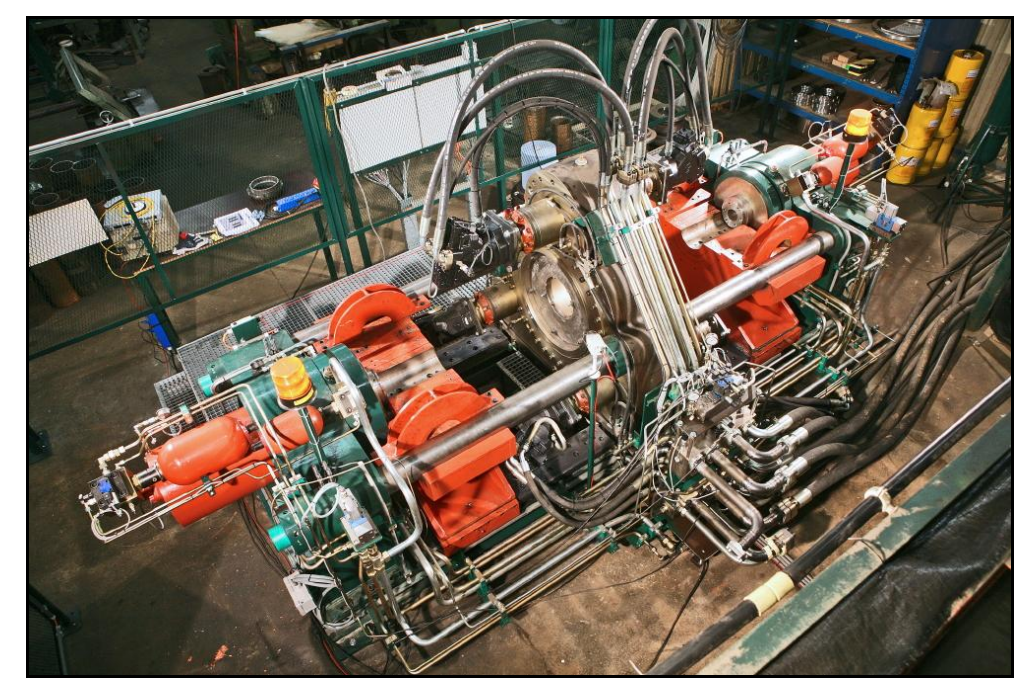

Figure 2. Large scale test set-up

The rotational speed, the axial friction and forge force and the friction time are the principle variables that are controlled in order to provide the necessary combination of temperature and pressure to form the weld. The heating time is controlled by measuring the axial shortening during the weld cycle. Sufficient material must be consumed to assure adequate heating prior to forging. When the predetermined shortening of the pipe ends is attained, the welding ring is decelerated and the axial force is increased to the forge force to cause additional shortening.

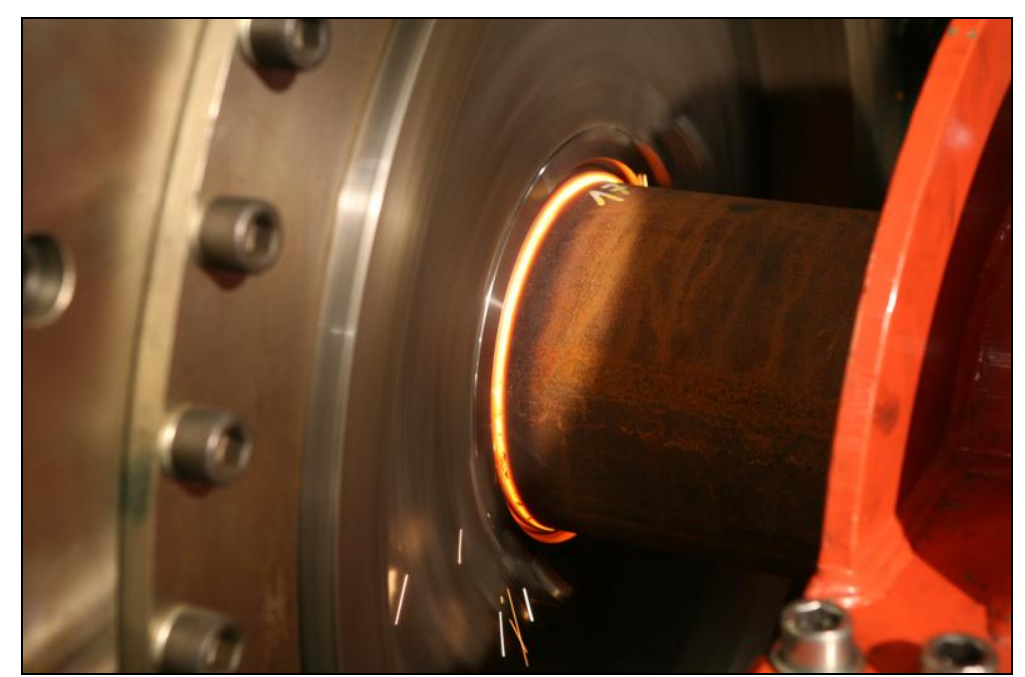

Figure 3. Welding experiment

\section{WELDING EXPERIMENTS WITH API-5L X65 PIPELINE STEEL}

\subsection{Materials}

For investigating the feasibility of the use of the new welding process for joining high-strength micro-alloyed pipeline steels, exploratory welding trials were performed with the quenched and tempered micro-alloyed high-strength pipeline steel API-5L X65. The yield stress, tensile strength, impact toughness and hardness were equal to respectively 487-534 MPa, 533-608 MPa, $260 \mathrm{~J}\left(\right.$ at $\left.-20^{\circ} \mathrm{C}\right)$ and $193 \mathrm{HV} 1$. For the welding ring the high-strength thermomechanically rolled steel with accelerated cooling EN 10225 S460G2+M was used. The yield stress, tensile strength, impact toughness and hardness were equal to respectively $495 \mathrm{MPa}$, $630 \mathrm{MPa}, 342 \mathrm{~J}$ (at $-20^{\circ} \mathrm{C}$ ) and $196 \mathrm{HV} 1$. The chemical composition of these materials is specified in Table 1. 
The utilised pipes have a diameter and a wall thickness of respectively 219,1 and $8,2 \mathrm{~mm}$. The thickness of the welding ring was equal to $15 \mathrm{~mm}$.

\begin{tabular}{|c|c|c|c|c|c|c|c|c|c|c|c|}
\hline \multicolumn{10}{|c|}{ Chemical composition of API-5L X65 } \\
\hline $\mathbf{C}$ & $\mathbf{S i}$ & $\mathbf{M n}$ & $\mathbf{S}$ & $\mathbf{P}$ & $\mathbf{A l}$ & $\mathbf{C r}$ & $\mathbf{N i}$ & $\mathbf{M o}$ & $\mathbf{C u}$ & $\mathbf{V}$ \\
\hline 0,092 & 0,235 & 1,30 & 0,0015 & 0,009 & 0,026 & 0,044 & 0,149 & 0,160 & 0,168 & 0,005 \\
\hline $\mathbf{A s}$ & $\mathbf{S n}$ & $\mathbf{T i}$ & $\mathbf{N b} / \mathbf{C b}$ & $\mathbf{N}$ & $\mathbf{P b}$ & $\mathbf{B}$ & $\mathbf{C a}$ & $\mathbf{B i}$ & $\mathbf{C e q}$ & \\
\hline 0,0030 & 0,0050 & 0,002 & 0,031 & 0,0079 & 0,001 & 0,0001 & 0,0022 & 0,0009 & 0,37 & \\
\hline \multicolumn{10}{|c|}{ Chemical composition of S460G2+M } \\
\hline $\mathbf{C}$ & $\mathbf{S i}$ & $\mathbf{M n}$ & $\mathbf{S}$ & $\mathbf{P}$ & $\mathbf{C r}$ & $\mathbf{~ N i}$ & $\mathbf{M o}$ & $\mathbf{C u}$ & $\mathbf{V}$ & $\mathbf{A l}$ \\
\hline 0,039 & 0,340 & 1,650 & 0,0010 & 0,010 & 0,170 & 0,017 & 0,001 & 0,014 & 0,002 & 0,038 \\
\hline $\mathbf{T i}$ & $\mathbf{N}$ & $\mathbf{B}$ & $\mathbf{N b}$ & $\mathbf{C e q}$ & & & & & & \\
\hline 0,014 & 0,0042 & 0,0002 & 0,038 & 0,35 & & & & & & \\
\hline
\end{tabular}

Table 1. Chemical composition of the materials used (in wt\%)

\subsection{Process parameters}

After the pipe ends are brought into initial contact with the welding ring, the latter is accelerated and a stepped pressure cycle is applied [9-13]. At the beginning of the friction phase the pipes are in contact under an initial low axial contact pressure $p_{0}$, which is used to achieve some pre-heating and to reduce the coefficient of friction before the contact pressure is increased. During this phase, considerable power is required to rotate the welding ring, since the friction torque can be quite high during this stage of the process. A low contact pressure is therefore used in order to prevent stalling of the drive motor or to limit the required drive power. The initial stage continues for a predetermined time $t_{0}$. Subsequently the axial pressure is increased proportionally, and after the time duration $t_{1}$, the pressure is increased to the second friction pressure $p_{2}$.

During the second friction phase, the pipe ends and welding ring deform plastically and the characteristic flashes are formed. The displacement of material (usually called "burn-off") ensures that contaminants are removed from the weld interface. When the pre-set shortening per pipe end $\left(\Delta \mathrm{I}_{\text {set }}\right)$ is reached, the welding ring is decelerated in a duration $t_{d e c}$. After the delay time $t_{d}$, the second friction phase ends and the contact pressure is increased to the forge pressure $p_{f}$. Forging can take place when the rotation of the welding ring has completely stopped $\left(t_{d}>t_{d e c}\right)$, or while the welding ring is still in motion, dependant on the parameter settings of $t_{d}$ and $t_{d e c}$. The shortening during the pressure increase from $p_{2}$ to $p_{f}$ is equal to $\Delta l_{f, p}$. When using a long deceleration an additional shortening $\Delta \mathrm{l}_{\mathrm{f}, \mathrm{d}}$ takes place during the forge phase. The total shortening during forging equals $\Delta l_{f}$ (see Figure 4). 


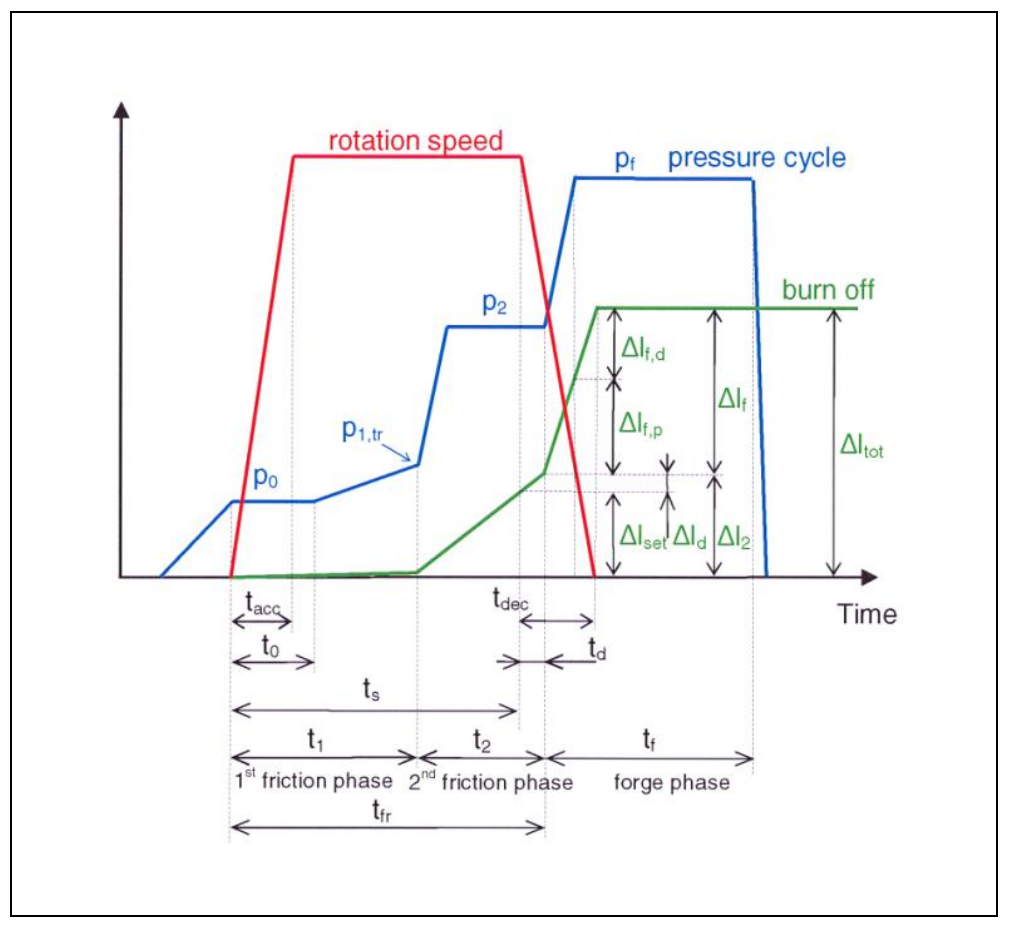

Figure 4. Process parameters of the process

After performing preliminary welding trials, 3 welds were selected for further evaluation. The three welds were performed with the same contact pressure during the weld cycle (first stage friction pressure: 5,5 MPa; second stage friction pressure: 55,2 MPa; forge pressure: 107,7 MPa). The allowable shortening during the friction phase and the rotation speed of the welding ring was varied. The variation of these parameters resulted in a different duration of the friction phase ( $\left.t_{\mathrm{fr}}\right)$ and heat input. A smaller allowable shortening and a lower rotation speed results in a smaller friction time and heat input:

- Weld 1: $n_{\mathrm{wr}}=130 \mathrm{rpm} ; \Delta \mathrm{I}_{\mathrm{set}}=5,5 \mathrm{~mm}$ resulted in a friction time $\mathrm{t}_{\mathrm{fr}}$ of $15,0 \mathrm{sec}$,

- Weld 2: $n_{\mathrm{wr}}=180 \mathrm{rpm} ; \Delta \mathrm{l}_{\mathrm{set}}=4,0 \mathrm{~mm}$ resulted in a friction time $\mathrm{t}_{\mathrm{fr}}$ of $13,8 \mathrm{sec}$,

- Weld 3: $\mathrm{n}_{\mathrm{wr}}=130 \mathrm{rpm} ; \Delta \mathrm{l}_{\mathrm{set}}=4,0 \mathrm{~mm}$ resulted in a friction time $\mathrm{t}_{\mathrm{fr}}$ of $12,0 \mathrm{sec}$.

\subsection{Visual examination of the welds}

All welds were visually examined. No weld defects or misalignment were observed. Figure 5 shows weld 2 in the as-welded condition.

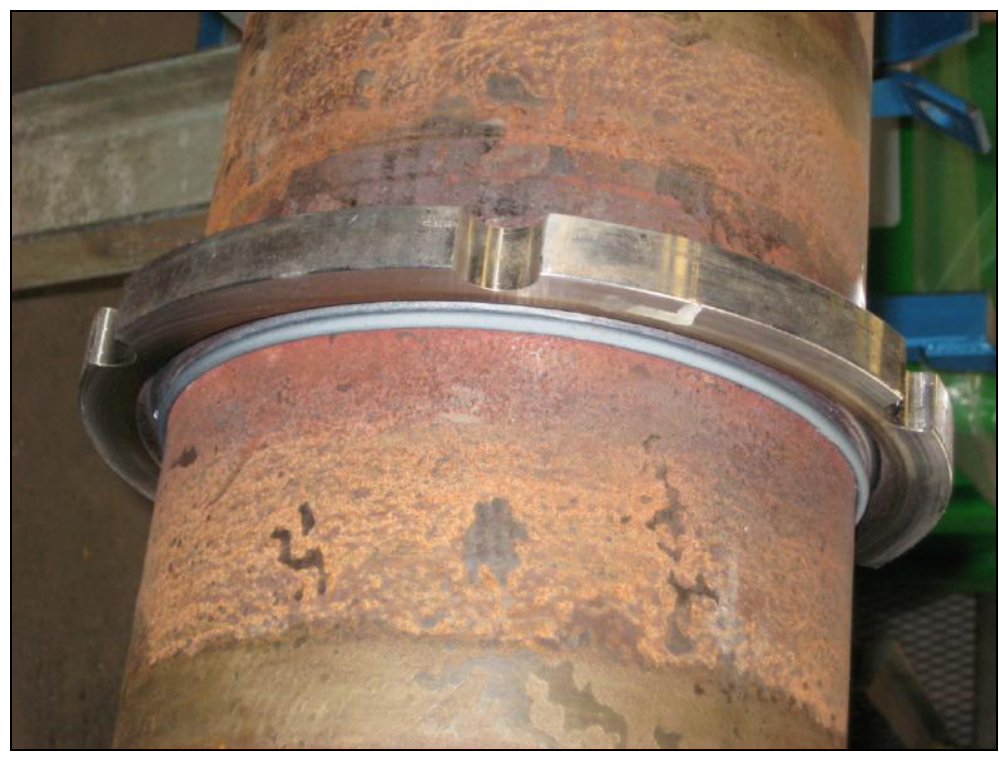

Figure 5. Visual examination of weld 2 


\subsection{Weld quality assessment}

The weld quality was assessed based on metallographic examinations, tensile, bending and Charpy impact testing. The tensile test specimens were prepared according to EN 895. The test specimens made from the 3 welds fractured in the pipe base material, at a tensile strength equal to the pipe base material tensile strength. Face and root bending tests were performed according to EN 910. All test specimens could be bent to an angle of $180^{\circ}$ without fracture.

Charpy impact tests were performed in accordance with EN 875. For each weld 3 sets of at least 6 impact tests were carried out. Three types of test specimens were used, based on the position of the notch. The specimens were taken out axially and the notch was always located through the thickness, either in the middle of the welding ring, or at the left or at the right weld interface. The tests were performed with subsized specimens with a thickness of $5 \mathrm{~mm}$. The measured energy was converted proportionally to the impact energy of standard specimens. In EN 12732 an average impact energy of $40 \mathrm{~J}$ is required, with the individual values not lower than $30 \mathrm{~J}$ for steel grades with a specified minimum yield stress higher than $360 \mathrm{MPa}$. The testing temperature is equal to the minimum design temperature (in Belgium: $-20^{\circ} \mathrm{C}$ ).

The impact toughness of the 3 investigated welds is shown in Figure 6 as a function of the total heat input. The heat input was calculated based on the measurement of the friction torque, the rotation speed and the friction duration. At the weld interface, the highest impact toughness is obtained for the lowest heat input. The impact toughness decreases for a higher heat input. The impact toughness measured in the middle of the welding ring is always high and not dependent on the heat input.

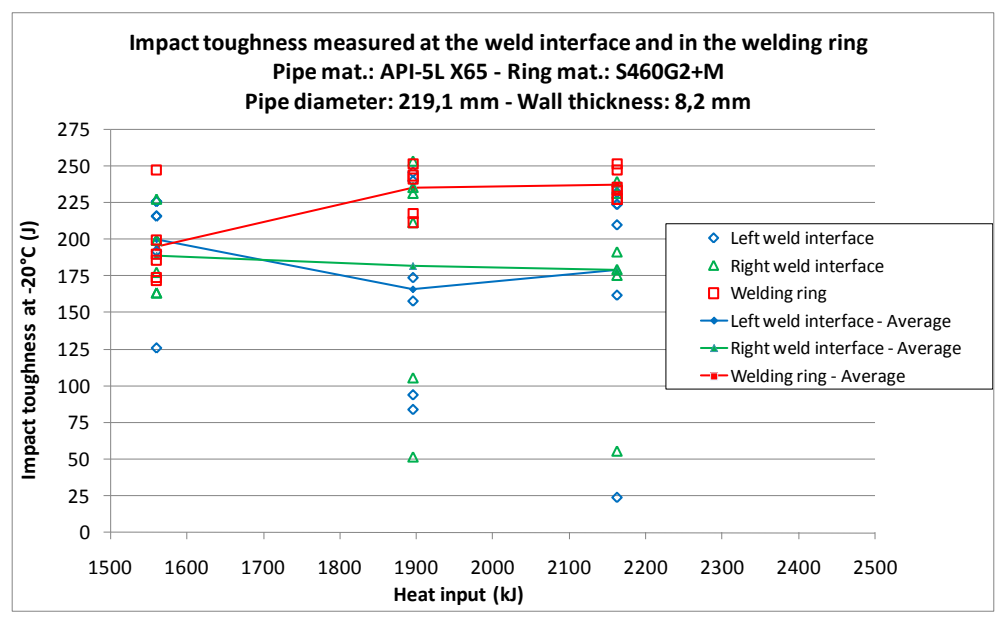

Figure 6. Charpy impact toughness as function of the heat input

The microstructure at the weld interface of weld 1 and 3 is shown in Figure 7. In the pipe heat affected zone (HAZ) the microstructure consists of ferrite with aligned second phase [14]. In the welding ring HAZ a similar microstructure is observed, but with a smaller amount of aligned second phase. The finest microstructure and the smallest HAZ is observed in weld 3 , realised with the lowest heat input. In the middle of the welding ring of all welds, a microstructure similar to the base material microstructure is observed.

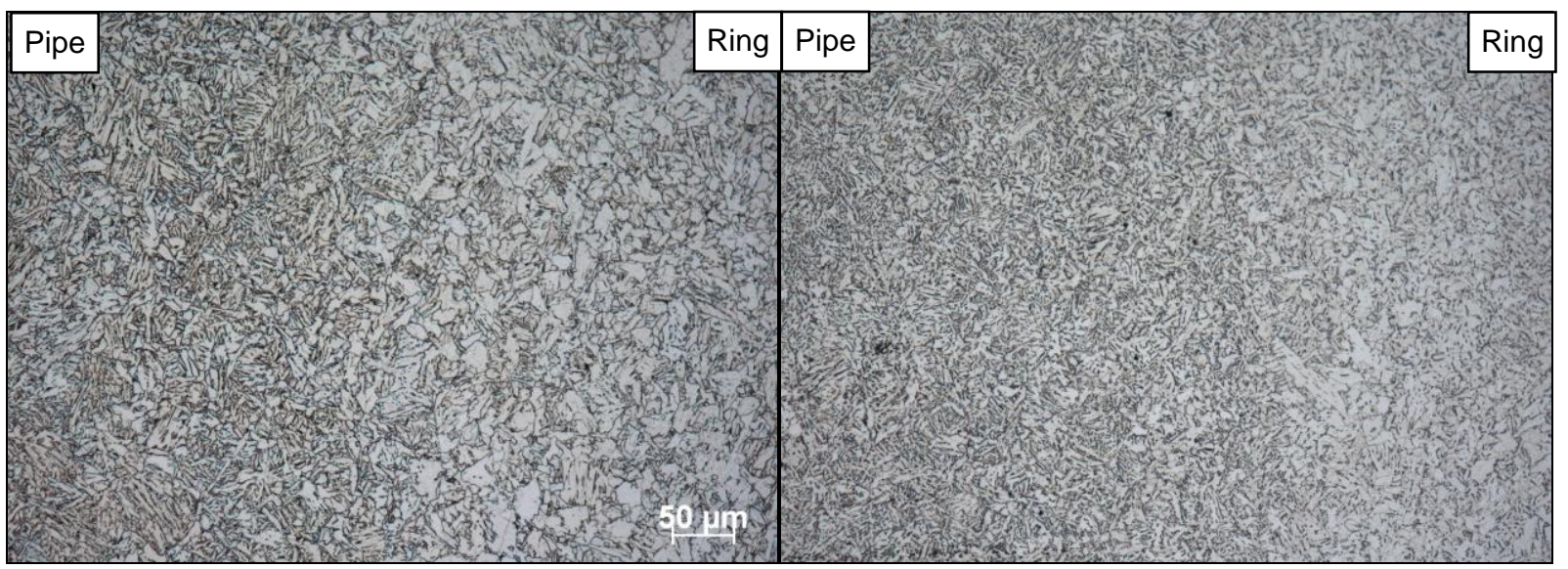

Figure 7. Microstructure at the weld interface of weld 1 (left) and 3 (right) 
The hardness profile of the welds is shown in Figure 8. In the pipe HAZ of all welds, the hardness decreases below the base material hardness value (193 HV1), at 2 to $6 \mathrm{~mm}$ from the weld interface. Also in the welding ring HAZ softening is observed (hardness ring base material: $196 \mathrm{HV} 1$ ). The width of the softened zone decreases for a lower heat input. Weld 3, executed with the lowest heat input, contains the smallest softened zone. Also the hardness decrease is minimal for this weld.

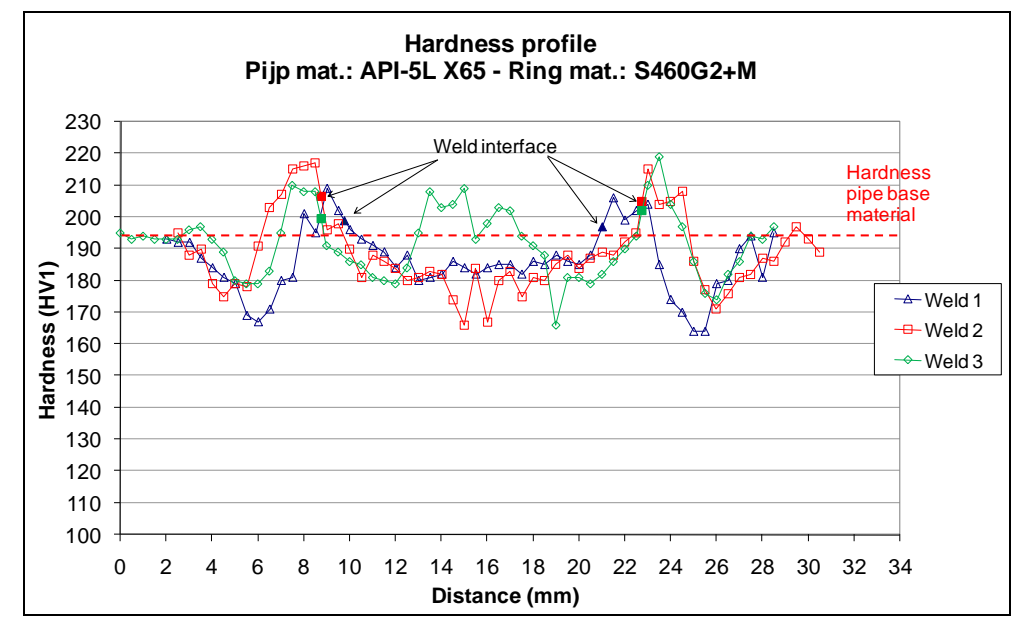

Figure 8. Hardness profile of the investigated welds

\section{CONCLUSIONS}

A new friction welding process was developed for automatic joining of pipelines. After investigating the weldability of normalised pipeline steels, welding trials were performed to study the weldability of the microalloyed high-strength pipeline steels. The investigation was performed with the quenched and tempered steel API-5L X65.

The parameter settings for obtaining a good weld quality were defined. When welding this material using a sufficient low heat input (corresponding welding time: $12 \mathrm{sec}$ ), good mechanical properties were obtained. An appropriate welding ring material was determined (the TMCP-steel EN 10225 S460G2+M). Under these conditions the HAZ microstructure is fine grained and consists of ferrite with aligned second phase. Softening in the pipe and welding ring material was observed, but was in none of the welds problematic, since the tensile test specimens always broke in the pipe base material. The impact toughness decreases for a higher heat input. When welding with a heat input of $1550 \mathrm{~kJ}$ a high impact toughness was obtained $\left( \pm 200 \mathrm{~J}\right.$ at $\left.-20^{\circ} \mathrm{C}\right)$, as well as at the weld interface as in the welding ring.

The finest microstructure was observed in the weld realised with the lowest heat input. The HAZ hardness decreased and the width of the softened zone increased for a higher heat input. In the weld realised with the lowest heat input the hardness decreased from 193 HV1 (pipe base material) to 175-180 HV1.

\section{ACKNOWLEDGEMENTS}

The authors gratefully acknowledge the financial support from the IWT (Institute for the Promotion of Innovation by Science and Technology in Flanders).

\section{REFERENCES}

[1]: SIMDEX Future Pipeline Projects Worldwide Guide - Update May 2008 (http://www.simdex.com)

[2]: S.A. Blackman, D.V. Dorling, Advanced welding processes for transmission pipelines, Proceedings of the 3rd International Pipeline Technology Conference, Brugge, Belgium, May 21-24, 2000, 371387.

[3]: D. Yapp, S.A. Blackman, Recent developments in high productivity pipeline welding, IIW Doc. No. XII-1786-2004.

[4]: Y. Gainand, J.P. Mas, J.P. Jansen, J.C. Coiffier, J.C. Dupont, C. Vauthier, Laser orbital applied to offshore pipe line construction, Proceedings of the 3rd International Pipeline Technology Conference, Brugge, Belgium, May 21-24, 2000, 327-342. 
[5]: Y. Hara, M. Toyoda, M. Ushio, H. Irie, H. Masuda, T. Yamakawa, Development of electron beam welding for girth welding of gas transmission pipelines, Proceedings of the 3rd International Pipeline Technology Conference, Brugge, Belgium, May 21-24, 2000, Vol. II, 343-357.

[6]: S.I. Kuchuk-Yatsenko, A.S. Nikitin, Flash butt welding of pipes from stainless steels, Stainless Steel World, Sept. 1999, 43-49.

[7]: L. Fletcher, C. Stubbs, G. Stecher, Developments in the application of MIAB welding of pipelines, Proceedings of the 4th International Pipeline Technology Conference, Ostend, Belgium, May 9-13, 2004. Vol I, 315-323.

[8]: Welding Handbook, 8th Edition, Vol. 2, Chapter 23 - American Welding Society, 1991, p 739 - 763.

[9]: K. Faes, A. Dhooge, O. Jaspart, L. D'Alvise, P. Afschrift, P. De Baets, New friction welding process for pipeline girth welds: parameter optimization, Proceedings of the Institution of Mechanical Engineers. Part B. Journal of engineering manufacture, vol. 221, no 5, 2007, 897-907.

[10]: K. Faes, A. Dhooge, P. De Baets, E. Van Der Donckt, W. De Waele, Parameter optimisation for automatic pipeline girth welding using a new friction welding method, Materials and Design 30, 2009, 581-589.

[11]: K. Faes, W. Vermeirsch, P De Baets, R. Denys, E. Van Der Donckt, Influence of forge pressure on properties of friction welded pipelines using intermediate ring, Science and Technology of Welding \& Joining, Vol. 13, No. 5, July 2008, 445-451 (7).

[12]: K. Faes, A. Dhooge, P. De Baets, P. Afschrift, New friction welding process for pipeline girth welds welding time optimization, The International Journal of Advanced Manufacturing Technology, Vol 43, No. 9-10, August, 2009, 982-992. DOI 10.1007/s00170-008-1775-z

[13]: K. Faes, A. Dhooge, P. De Baets, P. Afschrift, Influence of deceleration phase on properties of friction welded pipelines using intermediate ring, Science and Technology of Welding \& Joining, Vol. 13, No. 2, Febr. 2008 , 136-145 (10).

[14]: Guide to the light microscope examination of ferritic steel weld metals. Welding in the World, 1991; 29 (7/8), 160 - 176. (IIW Doc.No.IX-1533-88, June 1988). 